\title{
Total Synthesis of Native 5,7-Diacetylpseudaminic Acid from
}

\section{N-Acetylneuraminic Acid}

\author{
James T. Williams ${ }^{\mathrm{a}}$, Leo Corcilius ${ }^{\mathrm{a}}$, Milton J. Kiefel ${ }^{\mathrm{b}}$, Richard J. Payne ${ }^{\mathrm{a} *}$
}

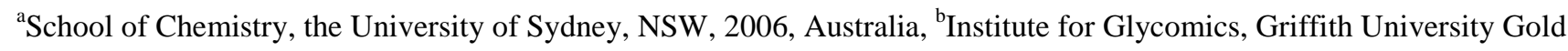

Coast Campus, Southport, QLD, 4222, Australia

\begin{abstract}
The pseudaminic acids are a family of 5,7-diamino-3,5,7,9-tetradeoxynonulosonic acids that are functional components of flagellin and pili proteins within clinically-relevant Gram-negative bacteria. Herein, we describe the total synthesis of the most common pseudaminic acid, 5,7-diacetylpseudaminic acid from $N$-acetylneuraminic acid. The divergent nature of the route reported here provides a robust and versatile means to access other members of the family, together with analogues, for probing the functional role of the pseudaminic acids and pseudaminic acid-derived proteins in the future.
\end{abstract}

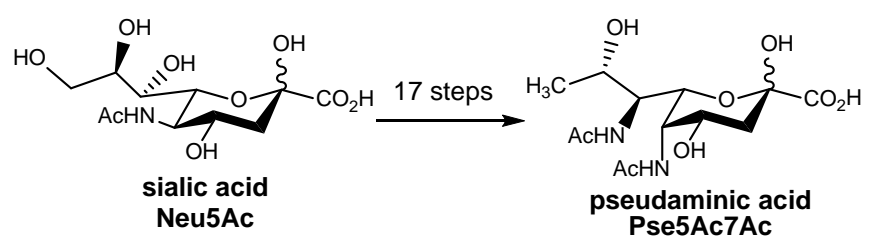

The pseudaminic acids belong to a class of 5,7-diamino-3,5,7,9-tetradeoxynonulosonic acid carbohydrates. The most common member of the family is 5,7-diacetylpseudaminic acid (Pse5Ac7Ac, 1, Figure 1) and is structurally related to the well-studied sialic acids, including $N$ acetylneuraminic (Neu5Ac, 2) and related keto-deoxynonulosonic acid (KDN, 3). Together, this family of diverse nonulosonic acid carbohydrates is known to have critical roles in a variety of important biological and pathological processes. ${ }^{1-7}$ Recently, the pseudaminic acids and the structurally related legionaminic acid (Leg, 4) have been the subject of significant interest owing to their importance in the virulence of many clinically relevant, gram-negative bacterial pathogens. ${ }^{8-10}$ To date, Pse5Ac7Ac (1) and analogues (Pse5Am7Ac, 5 and Pse5Ac7NHCOCH$\left.{ }_{2} \mathrm{CH}(\mathrm{OH}) \mathrm{CH}_{3}, \mathbf{6}\right)$ have been identified in several pathogenic gram-negative bacteria including Campylobacter jejuni ${ }^{11-}$ ${ }^{15}$, Helicobacter pylori, ${ }^{16,17}$ Pseudomonas aeruginosa, ${ }^{18,19}$ Shigella bodyii, ${ }^{18,19}$ Acinetobacter baumannii ${ }^{20}$ and Aeromonas species. ${ }^{21,22}$ Structural variations within the pseudaminic acid family, whereby different acyl groups are appended at C-5 and C-7, are common amongst different pathogens. However, the functional significance of the different modifications have not been elucidated to date owing, in major part, to the difficulty in accessing these molecules in homogeneous form and in sufficient quantities. ${ }^{8,9}$

Whilst the precise role(s) that pseudaminic acids play in virulence of bacterial organisms has not been elucidated, it is known that opportunistic bacterial species often decorate their flagella and pili with these nonulosonic acids ${ }^{8,9,11-22}$ Pseudaminylation of proteins has been 
demonstrated to aid in bacterial motility, and hence colonization, and is therefore considered an important virulence factor for bacteria that utilize this carbohydrate. ${ }^{16,23}$ The importance of the pseudaminic acids is further demonstrated by decreased motility in $C$. jejuni, leading to reduced adherence and virulence, when the pseudaminic acid biosynthetic enzymes are mutated. ${ }^{24}$ It has recently been demonstrated that post-translational pseudaminylation is necessary for the assembly of functional flagella. For pathogenic organisms such as $C$. jejuni, $H$. pylori and P. aeruginosa that utilize highly efficient flagellin motility in order to colonize thickened mucosal surfaces, e.g. gastric lumen and the lower respiratory tract, a loss of motility caused by a lack of pseudaminic acid expression is detrimental to growth and survival. ${ }^{24,25}$ As a result, $O$-linked pseudaminylation and the biosynthesis of the corresponding nonulosonic acids have recently been targeted for the development of antimicrobials against Helicobacter pylori infection. This research area is particularly attractive given the exclusivity of the carbohydrates to bacteria. ${ }^{26}$
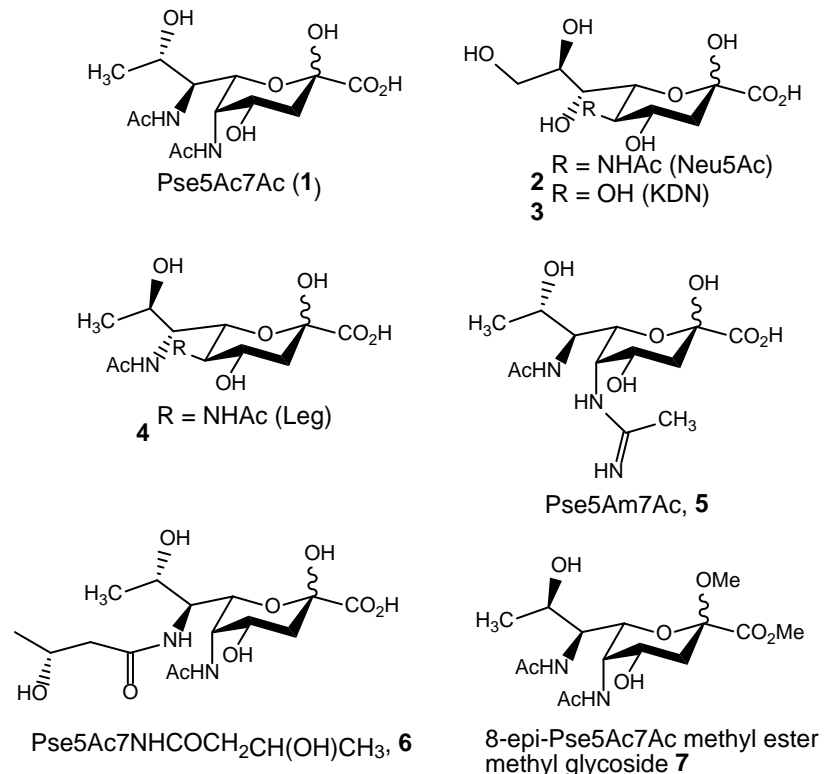

Figure 1. Structures of common nonulosonic acids (1-6) and Pseudaminic acid analogue 7

The potential role of the pseudaminic acids as virulence factors in several gram-negative bacteria has also sparked efforts in accessing these nonulosonic acids in homogeneous form. To date, efforts towards this end have involved a chemoenzymatic approach utilizing the enzymes involved in pseudaminic acid biosynthesis ${ }^{27,28}$, as well as multi-step synthetic approaches ${ }^{29,30}$. Two synthetic routes have been reported to date that utilize late stage C-C bond forming reactions that are poor yielding. In addition, these synthetic routes lack the divergence and flexibility that would enable facile access to the family of pseudaminic acids and their analogues. We report here the successful synthesis of native 5,7-diacetylpseudaminic acid (Pse5Ac7Ac, 1) from the commercially available, inexpensive sialic acid (2). It is envisaged that the divergent nature of the synthetic route should provide an avenue to the generation of other native pseudaminic acids and analogues in the future.

We originally sought to prepare the most common member of the pseudaminic acid family, Pse5Ac7Ac 1, via manipulation of a precursor in the synthesis of 8-epi-5,7-diacetylpseudaminic acid methyl ester methyl glyccoside 7 reported previously (see Supporting Information). ${ }^{31}$ Unfortunately 7 proved to be an intractable substrate for this purpose due to the inability to invert the stereochemistry of the 
hydroxyl moiety at the C-8 position. The difficulty in inverting the C-8 hydroxyl in 7 was attributed to an intramolecular H-bonding interaction between the C-8 hydroxyl and the C-7 $\mathrm{N}$-acetyl moiety that made the C-8 hydroxyl resistant to both activation as well as inversion via $\mathrm{S}_{\mathrm{N}} 2$ chemistry (see Supporting Information). We therefore turned our attention to an alternate synthetic route that would be amenable to the synthesis of native pseudaminic acid $\mathbf{1}$. To this end, suitably protected bis-azide $\mathbf{8}$ was interrogated as a precursor. The bis-azide was prepared in 8 steps from commercially available Neu5Ac, 2 as previously reported by Zunk et al. ${ }^{31}$ (Scheme 1). Given the challenges associated with inversion of the C-8 hydroxyl in 7, we sought to invert the stereochemistry at this position as soon as possible in our synthetic route. As such, deprotection of the 8,9-O-isopropylidene using dilute aqueous trifluoroacetic acid (50\%) provided the 8,9-diol in excellent yield (88\%). The C-9 hydroxyl was subsequently protected regioselectively as a tert-butyldimethylsilyl (TBS) ether by treatment with TBS-Cl and imidazole to afford $\mathbf{8}$ in 98\% yield. With 8 in hand, we next attempted to invert the C-8 hydroxyl moiety. While a number of one-pot methods failed to afford the desired inversion product in appreciable yields, an oxidation-reduction approach proved successful. Specifically, oxidation with Dess-Martin periodinane provided the corresponding ketone, which was selectively reduced with borane-THF complex to afford predominantly stereoisomer $\mathbf{1 0}$ with the desired inverted C-8 stereochemistry which could be easily separated from undesired epimer 9 by column chromatography and isolated in $74 \%$ yield.

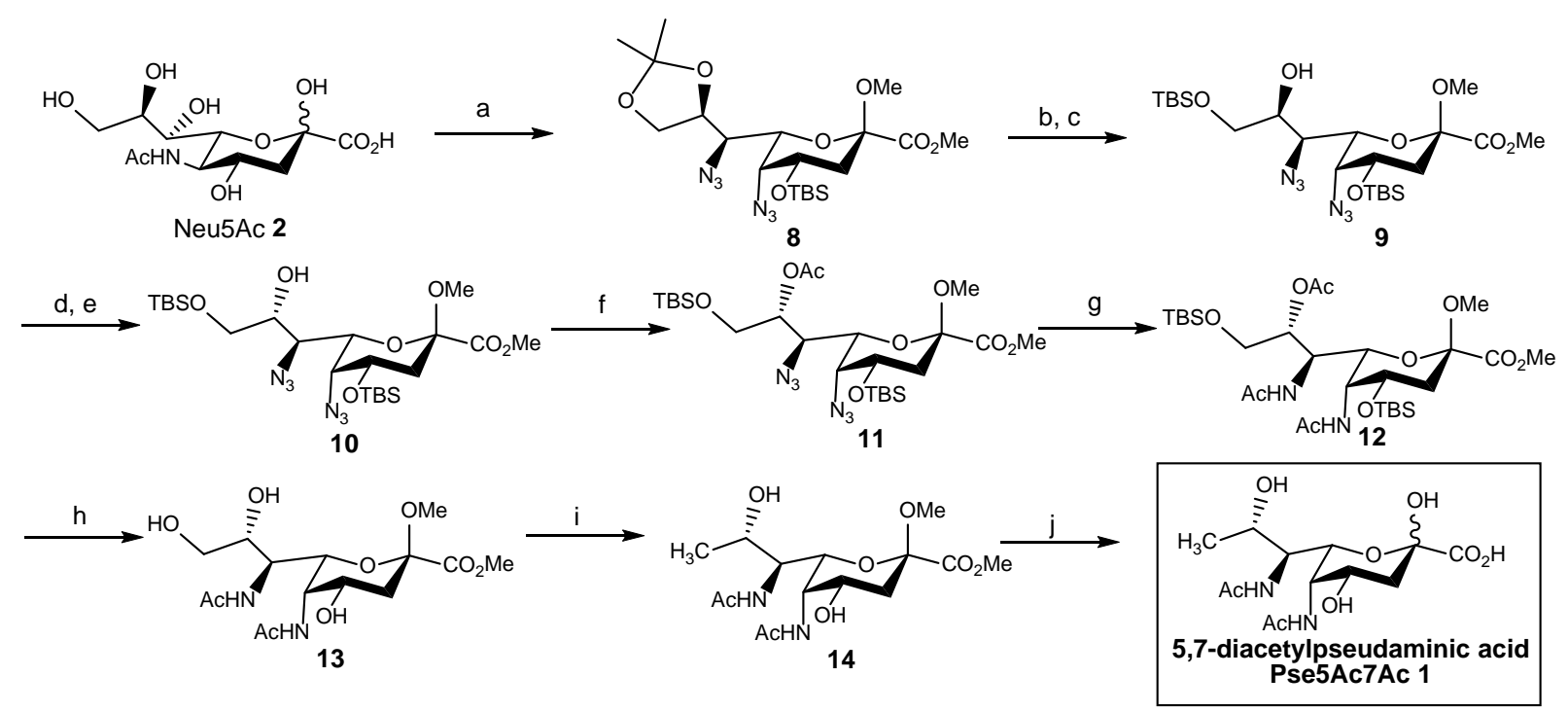

Scheme 1: Synthesis of pseudaminic acid Pse5Ac7Ac 1. a) 8 steps $^{31}$ (27\% yield over 8 steps); b) $50 \%$ aq. $\mathrm{TFA} \mathrm{CH}_{2} \mathrm{Cl}_{2}, 0{ }^{\circ} \mathrm{C}$ to $25{ }^{\circ} \mathrm{C}(2$ h), 88\%; c) TBDMS-Cl, imidazole, DMF, 16 h, $25^{\circ} \mathrm{C}, 98 \%$; d) Dess-Martin Periodinane, $\mathrm{CH}_{2} \mathrm{Cl}_{2}, 2 \mathrm{~h}, 25^{\circ} \mathrm{C}, 93 \%$; e) $\mathrm{BH}{ }^{\circ} \mathrm{THF}, \mathrm{THF}, 16$ h, $25^{\circ} \mathrm{C}$, 74\%; f) $\mathrm{Ac}_{2} \mathrm{O}$, Pyr, DMAP, $12 \mathrm{~h}, 25^{\circ} \mathrm{C}, 93 \%$; g) (i) $p-\mathrm{TSOH} \cdot \mathrm{H}_{2} \mathrm{O}, \mathrm{Pd}(\mathrm{OH})_{2} / \mathrm{C}\left(20 \%\right.$ wt), $\mathrm{H}_{2}, \mathrm{MeOH}^{\circ} 4 \mathrm{~h}, 25{ }^{\circ} \mathrm{C},(\mathrm{ii}) \mathrm{Ac} \mathrm{C}_{2} \mathrm{O}, \mathrm{Pyr}$, 12h, $25^{\circ} \mathrm{C}$, 79\% over two steps; h) (i) TFA, THF: $\mathrm{H}_{2} \mathrm{O}$ (4:1 v/v), $30 \mathrm{~min}, 25^{\circ} \mathrm{C}$, (ii) $\mathrm{NaOMe}, \mathrm{MeOH}, 2 \mathrm{~h}, 25^{\circ} \mathrm{C}, 71 \%$ over two steps; i) (i) $\mathrm{I}_{2}, \mathrm{PPh}_{3}$, Imidazole, THF, $2 \mathrm{~h}, 60^{\circ} \mathrm{C}$, (ii) $\mathrm{iPr}_{2} \mathrm{EtN}, \mathrm{Pd}(\mathrm{OH})_{2} / \mathrm{C}(20 \% \mathrm{wt}), \mathrm{H}_{2}, \mathrm{MeOH}, 16 \mathrm{~h}, 25^{\circ} \mathrm{C}, 44 \%$ over two steps; j) (i) aq. NaOH (1 $\mathrm{M}), 1 \mathrm{~h}, 40^{\circ} \mathrm{C}$, (ii) Dowex-50WX8 $\left(\mathrm{H}^{+}\right), 36 \mathrm{~h}, 80^{\circ} \mathrm{C}$, $38 \%$ over two steps.

Having successfully prepared $\mathbf{1 0}$ we next attempted direct reductive acetylation of the azides at C-5 and C-7. Unfortunately, this substrate was resistant to reduction under a number of conditions. This observation was consistent with a recent report of reduction-acetylation on partially protected carbohydrates, which led to poor yields, together with difficulties with product purification. ${ }^{32}$ We envisaged that the free hydroxyl at C-8 may have prohibited the reduction of the adjacent C-7 azide. As such, we next acetylated $\mathbf{1 0}$ to afford $\mathbf{1 1}$ which enabled smooth reduction of both azide groups. Optimal conditions involved hydrogenation with Pearlman's catalyst in the presence of catalytic $p$ - 
toluenesulfonic acid. It should be noted that the inclusion of the catalytic acid was necessary to avoid the formation of a lactam by-product resulting from intramolecular attack of the C-5 amine (generated from reduction of the C-5 azide) onto the carbonyl of the methyl ester at

$\mathrm{C}-1 .{ }^{31}$ Following the reduction step and without purification, acetylation of the C-5 and C-7 amine moieties proceeded smoothly to provide 12 in $79 \%$ yield over the two steps.

Having accessed 12 bearing the required 5,7-bis-acetamide functionalities present in Pse5Ac7Ac (1), a number of deprotection steps were next required to facilitate deoxygenation at C-9. To this end, acidolytic deprotection of the silyl ethers at C-4 and C-9, followed by deacetylation at C-8 under Zemplén conditions provided triol 13 in 71\% over the two steps. With triol 13 now in hand, we could proceed with deoxygenation at C-9. This was achieved via iodination, followed by hydrodeiodination with Pearlman’s catalyst in the presence of Hünig’s base and an atmosphere of hydrogen, to afford 9-deoxy derivative $\mathbf{1 4}$ in $44 \%$ yield over the two steps. The final steps to access native Pse5Ac7Ac $\mathbf{1}$ involved deprotection of the methyl ester and the methyl glycoside at C-1. Hydrolysis of the methyl ester of $\mathbf{1 4}$ could be smoothly effected through saponification. Surprisingly, there are a dearth of methods reported in the literature for the hydrolysis of glycosides from nonulosonates, ${ }^{33}$ and the use of standard acidic conditions normally employed for acetal hydrolysis in on carbohydrate substrates led to complex product mixtures. However, we found that treatment of the carboxylic acid with Dowex $50 \mathrm{WX} 8$ resin at $80^{\circ} \mathrm{C}$ for 36 hours afforded the globally deprotected native pseudaminic acid 1. Purification by reverse-phase HPLC provided Pse5Ac7Ac, 1 in 38\% yield over the two steps. Gratifyingly, the spectroscopic data for synthetic $\mathbf{1}$ was fully consistent with that reported for the natural product previously. ${ }^{27}$ The NMR data of our synthetic material showed that the dominant species present in aqueous solution is the $\alpha$-anomer, which has the carboxyl group in an equatorial orientation. ${ }^{29}$

In summary, we have reported the successful total synthesis of the most common member of the pseudaminic acid family, 5,7diacetylpseudaminic acid (Pse5Ac7Ac, 1). The synthesis was achieved in 17 steps from commercially available and affordable $N$ acetylneuraminic acid (Neu5Ac) as a privileged chiral precursor. The successful synthesis of $\mathbf{1}$ and the divergent route employed to access the natural product, should now pave the way for the efficient syntheses of other complex nonulosonic acids, including other members of the pseudaminic acid family, ketodeoxynonulosonic acids and legionaminic acids. Synthetic access to these molecules will provide a more detailed understanding of the role(s) of these carbohydrates in biology.

\section{Experimental Section}

Methyl (methyl-5,7-bis-azido-4,9-O-bis-(tert-butyldimethylsilyl)-3,5,7-trideoxy-D-glycero- $\beta$-L-manno-2-nonulopyranosid)onate (9). Diazide $\mathbf{8}^{31}$ (2.72 g, $\left.5.44 \mathrm{mmol}\right)$ was dissolved in $\mathrm{CH}_{2} \mathrm{Cl}_{2}(174 \mathrm{~mL})$ and the reaction cooled to $0{ }^{\circ} \mathrm{C}$. A solution of $1: 1 \mathrm{v} / \mathrm{v}$ trifluoroacetic acid: $\mathrm{H}_{2} \mathrm{O}(7.65 \mathrm{~mL})$ was added dropwise to the cooled, stirred solution. The resulting mixture was allowed to stir at $0{ }^{\circ} \mathrm{C}$ for 30 min, before being warmed to room temperature and stirred for a further $1 \mathrm{~h}$. The reaction was neutralized by the dropwise addition of triethylamine and concentrated in vacuo. The crude mixture was purified by flash chromatography (eluent 2:1 v/v Hex:EtOAc) to afford the corresponding diol as a colourless oil (2.20 g, 88\%). To a stirred solution of the diol (2.17 g, $4.71 \mathrm{mmol})$ in anhydrous DMF (20 mL) under argon was added tert-butyldimethylsilyl chloride $(923 \mathrm{mg}, 6.13 \mathrm{mmol})$ and imidazole (834 $\mathrm{mg}, 12.3 \mathrm{mmol})$. The resulting reaction mixture was allowed to stir at room temperature for $16 \mathrm{~h}$ under argon. The reaction mixture was concentrated to an oil which was diluted with methanol 
(5 mL) and EtOAc (30 mL) and adsorbed onto dry silica gel. Purification by flash column chromatography (eluent Hex/EtOAc v/v 6:1) provided the title compound $\mathbf{9}$ as a colorless oil (2.70g, 98\%). [ $\alpha]_{\mathrm{D}}-35.2$ (c 1.00, $\mathrm{CH}_{2} \mathrm{Cl}_{2}$ ); IR: 2954, 2929, 2857, 2109, 1752, 1258, 1099, 1041, 836, 777, $737 \mathrm{~cm}^{-1} ;{ }^{1} \mathrm{H}$ NMR $\left(\mathrm{CDCl}_{3}, 500 \mathrm{MHz}\right) \delta(\mathrm{ppm}) 4.34$ (m, 1H, H-4), 4.12 (m, 1H, H-8), 3.89 (dd, $1 \mathrm{H}, J_{7,6}=9.5 \mathrm{~Hz}, J_{7,8}=1.5$ Hz, H-7), 3.83 (dd, 1H, $J_{5,4}=2.0 \mathrm{~Hz}, J_{5,6}=1.0 \mathrm{~Hz}, \mathrm{H}-5$ ), 3.79 (s, 3H, COOCH $), 3.79$ (dd, 1H, $J_{9,8}=7.3 \mathrm{~Hz}, J_{9,9}=10.0 \mathrm{~Hz}, \mathrm{H} 9$ ), 3.74 (dd,

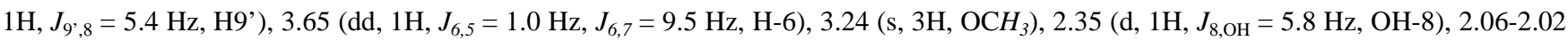
(m, 2H, H-3ax/H-3eq), 0.92, 0.92 (2 x s, 2 x 9H, 2 x C( $\left.\left(\mathrm{CH}_{3}\right)_{3}\right), 0.11-0.14$ (m, 4 x 3H, 2 x Si( $\left.\left.\mathrm{CH}_{3}\right)_{2}\right) ;{ }^{13} \mathrm{C} \mathrm{NMR}\left(\mathrm{CDCl}{ }_{3}, 125 \mathrm{MHz}\right) \delta(\mathrm{ppm})$ $168.3\left(\mathrm{CO}_{2} \mathrm{CH}_{3}\right), 99.5$ (C-2), 69.6 (C-8), 68.4 (C-7), 68.2 (C-4), 64.9 (C-9), 62.5 (C-6), 61.9 (C-5), $52.8\left(\mathrm{CO}_{2} \mathrm{CH}_{3}\right), 51.5\left(\mathrm{OCH}_{3}\right), 36.2(\mathrm{C}-$ 3), 26.0, $25.8\left(2 \times \mathrm{C}\left(\mathrm{CH}_{3}\right)_{3}\right), 18.5,18.1\left(2 \times \mathrm{SiC}\left(\mathrm{CH}_{3}\right)_{3}\right),-4.5,-4.6,-5.25,-5.31\left(2 \times \mathrm{Si}\left(\mathrm{CH}_{3}\right)_{2}\right)$; LRMS (+ESI) m/z= 597.13 [M+Na]+ HRMS (+ESI) Calc. for $\mathrm{C}_{23} \mathrm{H}_{46} \mathrm{~N}_{6} \mathrm{O}_{7} \mathrm{Si}_{2}[\mathrm{M}+\mathrm{Na}]^{+}$: 597.2859, found 597.2859.

\section{Methyl (methyl-5,7-bis-azido-4,9-O-bis-(tert-butyldimethylsilyl)-3,5,7-trideoxy-L-glycero- $\alpha$-L-manno-2-nonulopyranosid)onate (10).} To a stirred solution of 9 (2.70 g, $4.71 \mathrm{mmol})$ in anhydrous $\mathrm{CH}_{2} \mathrm{Cl}_{2}(20 \mathrm{~mL})$ cooled to $0{ }^{\circ} \mathrm{C}$ was added Dess-Martin periodinane (2.79 g, $6.59 \mathrm{mmol}$ ) under argon. The resulting reaction mixture was allowed to warm to room temperature and stirred for a further $2 \mathrm{~h}$. The reaction was diluted with $\mathrm{CH}_{2} \mathrm{Cl}_{2}(100 \mathrm{~mL})$ and $10 \%$ aqueous sodium thiosulfate solution $(30 \mathrm{~mL})$ added. The organic layer was separated, washed with $\mathrm{H}_{2} \mathrm{O}$, dried $\left(\mathrm{MgSO}_{4}\right)$ and concentrated in vacuo. Purification by flash column chromatography (eluent Hex/EtOAc v/v 7:1) afforded the corresponding ketone $(2.51 \mathrm{~g}, 93 \%)$ as a white solid. To a stirred solution of the ketone (1.75 g, $3.06 \mathrm{mmol})$ in anhydrous THF (34 mL) at $0{ }^{\circ} \mathrm{C}$ was added dropwise $\mathrm{BH}_{3} \cdot$ THF complex solution in THF (1 M, $12.23 \mathrm{~mL}, 12.23$ mmol) over 30 minutes under argon. At this stage, the reaction mixture was warmed to room temperature and allowed to stir for $16 \mathrm{~h}$ under argon. The crude reaction mixture was concentrated in vacuo, diluted with EtOAc $(100 \mathrm{~mL})$ and washed with $1 \mathrm{M}$ aqueous $\mathrm{HCl}$ (caution: gas evolved upon addition of $\mathrm{HCl})$. The organic phase was separated, dried $\left(\mathrm{MgSO}_{4}\right)$ and concentrated in vacuo. Flash chromatography (eluent Hex/EtOAc v/v 7:1) afforded the desired alcohol 10 (1.30 g, 74\%) together with epimer 9 (369 mg, 21\%). [ $\alpha]_{\mathrm{D}}-56.9$ (c 1.00, $\mathrm{CH}_{2} \mathrm{Cl}_{2}$ ); IR: 2954, 2930, 2858, 2111, 1754, 1259, 1148, 1099, 1046, 838, $779 \mathrm{~cm}^{-1} ;{ }^{1} \mathrm{H} \mathrm{NMR}\left(\mathrm{CDCl}_{3}, 500 \mathrm{MHz}\right) \delta(\mathrm{ppm}) 4.30\left(\mathrm{ddd}, 1 \mathrm{H}, J_{4,5}=3.4 \mathrm{~Hz}, J_{4,3 \mathrm{eq}}=5.1 \mathrm{~Hz}, J_{4,3 \mathrm{ax}}=10.9 \mathrm{~Hz}\right.$, H-4), 4.01-3.99 (m, 1H, H-8), 3.93-3.87 (m, 2H, H-7/H-9), 3.83 (m, 1H, H-5), 3.79 (s, 3H, COOCH ), 3.75-3.72 (m, 2H, H-6/H-9'), 3.20 (s, 3H, OCH $H_{3}$ ), 2.99 (s-br, 1H, OH-8), 2.06 (dd, 1H, $\left.J_{3 e q, 3 a x}=13.0 \mathrm{~Hz}, \mathrm{H} 3 e q\right), 2.01$ (dd, 1H, H3ax), $0.91,0.91$ (2 x s, 2 x 9H, 2 x C(CH $\left.)_{3}\right)$, 0.13-0.09 (m, 4 x 3H, 2 x Si $\left.\left(\mathrm{CH}_{3}\right)_{2}\right)$; ${ }^{13} \mathrm{C}$ NMR $\left(\mathrm{CDCl}_{3}, 125 \mathrm{MHz}\right) \delta(\mathrm{ppm}) 168.0\left(\mathrm{CO}_{2} \mathrm{CH}_{3}\right), 99.6$ (C-2), 73.4 (C-8), 70.1 (C-7), $68.0(\mathrm{C}-4)$, 64.4 (C-9), 62.4 (C-6), 61.8 (C-5), $\left.52.8\left(\mathrm{CO}_{2} \mathrm{CH}_{3}\right), 51.5\left(\mathrm{OCH}_{3}\right), 36.2(\mathrm{C}-3), 26.0,25.8\left(2 \times \mathrm{C}_{(} \mathrm{CH}_{3}\right)_{3}\right), 18.5,18.1\left(2 \times \mathrm{SiC}\left(\mathrm{CH}_{3}\right)_{3}\right),-4.5,-$ 4.6, -5.2, -5.3 (2 x Si(CH$\left.)_{2}\right)$; LRMS (+ESI) $\mathrm{m} / \mathrm{z}=597.13[\mathrm{M}+\mathrm{Na}]^{+}$; HRMS (+ESI) Calc. for $\mathrm{C}_{23} \mathrm{H}_{46} \mathrm{~N}_{6} \mathrm{O}_{7} \mathrm{Si}_{2}[\mathrm{M}+\mathrm{Na}]^{+}: 597.2859$, found 597.2860.

\section{Methyl (methyl-8-O-acetyl-5,7-bis-azido-4,9-O-bis-(tert-butyldimethylsilyl)-3,5,7-trideoxy-L-glycero- $\alpha$-L-manno-2-}

nonulopyranosid)onate (11). To a stirred solution of 10 (964 mg, $1.68 \mathrm{mmol})$ in anhydrous pyridine (9 mL) cooled to $0{ }^{\circ} \mathrm{C}$ was added acetic anhydride (3 mL) and DMAP ( 10 mg) under argon. The resulting reaction mixture was allowed to stir at room temperature under argon for $12 \mathrm{~h}$ before being concentrated in vacuo. The resulting residue was dissolved in EtOAc (75 mL), washed with $1 \mathrm{M}$ aqueous $\mathrm{HCl}$ (75 mL) and $\mathrm{H}_{2} \mathrm{O}(75 \mathrm{~mL})$. The organic phase was dried $\left(\mathrm{MgSO}_{4}\right)$ before concentrating in vacuo. Purification by flash column chromatography (eluent Hex/EtOAc 7:1 v/v) afforded 11 (965 mg, 93\%). [ $\alpha]_{\mathrm{D}}-49.5$ (c 1.00, $\mathrm{CH}_{2} \mathrm{Cl}_{2}$ ); IR: 2953, 2930, 2857, 2110, 1752, 1257, 1226, 
1105, 1042, 837, $778 \mathrm{~cm}^{-1} ;{ }^{1} \mathrm{H} \mathrm{NMR}\left(\mathrm{CDCl}_{3}, 400 \mathrm{MHz}\right) \delta(\mathrm{ppm}) 5.36$ (ddd, $\left.1 \mathrm{H}, J_{8,7}=2.4 \mathrm{~Hz}, J_{8,9}=5.2 \mathrm{~Hz}, J_{8,9},=6.8 \mathrm{~Hz}, \mathrm{H}-8\right), 4.24(\mathrm{~m}$, $1 \mathrm{H}, \mathrm{H}-4$ ), 4.00 (dd, $1 \mathrm{H}, J_{7,6}=10.0 \mathrm{~Hz}, J_{7,8}=2.4 \mathrm{~Hz}, \mathrm{H}-7$ ), 3.89 (dd, $1 \mathrm{H}, J_{9,8}=6.6 \mathrm{~Hz}, J_{9,9}$, = 10.7 Hz, H9), $3.81\left(\mathrm{dd}, 1 \mathrm{H}, J_{9}, 8=5.5 \mathrm{~Hz}\right.$, H9'), 3.78-3.77 (m, 4H, H-5, $\mathrm{COOCH}_{3}$ ), 3.74 (dd, 1H, $\left.J_{6,5}=1.2 \mathrm{~Hz}, J_{6,7}=10.0 \mathrm{~Hz}, \mathrm{H}-6\right), 3.23\left(\mathrm{~s}, 3 \mathrm{H}, \mathrm{OCH}_{3}\right), 2.09$ (s, 3H, OCOCH$)^{\text {), }}$ 2.03-2.01 (m, 2H, H-3ax/H-3eq), 0.91, 0.88 (2 x s, 2 × 9H, 2 x C $\left.\left(\mathrm{CH}_{3}\right)_{3}\right), 0.13-0.04$ (m, 4 x 3H, $\left.2 \times \mathrm{Si}\left(\mathrm{CH}_{3}\right)_{2}\right) ;{ }^{13} \mathrm{C} \mathrm{NMR}\left(\mathrm{CDCl}_{3}, 100\right.$ MHz) $\delta$ (ppm) $169.8\left(\mathrm{OCOCH}_{3}\right), 168.0\left(\mathrm{CO}_{2} \mathrm{CH}_{3}\right), 99.8$ (C-2), 73.9 (C-8), 69.5 (C-6), 67.9 (C-4), 62.6 (C-7), 62.1 (C-9), 61.6 (C-5), 52.9 $\left(\mathrm{CO}_{2} \mathrm{CH}_{3}\right), 51.8\left(\mathrm{OCH}_{3}\right), 36.1(\mathrm{C}-3), 25.9,25.8\left(2 \times \mathrm{C}\left(\mathrm{CH}_{3}\right)_{3}\right), 21.1\left(\mathrm{OCOCH}_{3}\right), 18.4,18.1\left(2 \times \mathrm{SiC}\left(\mathrm{CH}_{3}\right)_{3}\right),-4.5,-4.7,-5.3,-5.4(2 \times$ $\left.\mathrm{Si}\left(\mathrm{CH}_{3}\right)_{2}\right)$; HRMS (+ESI) Calc. for $\mathrm{C}_{25} \mathrm{H}_{48} \mathrm{~N}_{6} \mathrm{O}_{8} \mathrm{Si}_{2} 639.2964[\mathrm{M}+\mathrm{Na}]^{+}$:, found 639.2958.

\section{Methyl (methyl-5,7-bis-acetamido-8-O-acetyl-4,9-O-bis-(tert-butyldimethylsilyl)-3,5,7-trideoxy-L-glycero- $\alpha$-L-manno-2-}

nonulopyranosid)onate (12). To a stirred solution of 11 (535 mg, $0.87 \mathrm{mmol}$ ) in anhydrous methanol (14 mL) was added ptoluenesulfonic acid monohydrate $(8.26 \mathrm{mg}, 0.04 \mathrm{mmol})$ and $\mathrm{Pd}(\mathrm{OH})_{2} / \mathrm{C}(20 \%)(160 \mathrm{mg})$. The resulting reaction mixture was degassed and stirred under a hydrogen atmosphere at room temperature for $4 \mathrm{~h}$. The palladium catalyst was removed by filtration through Celite and the filtrate concentrated in vacuo. The crude residue was dissolved in acetic anhydride ( $3 \mathrm{~mL})$ and pyridine $(9 \mathrm{~mL})$ and the reaction mixture stirred for $16 \mathrm{~h}$ at room temperature under argon. Upon completion, the reaction mixture was concentrated in vacuo. Purification by flash column chromatography (eluent EtOAc/MeOH/Hex 45:5:50 v/v/v) afforded 12 (443 mg, 79\%). [ $\alpha]_{\mathrm{D}}-45.4$ (c 1.00, MeOH); IR: 3276, 2953, 2930, 2857, 1747, 1659, 1550, 1373, 1253, 1229, 1118, 1059, 837, $778 \mathrm{~cm}^{-1} ;{ }^{1} \mathrm{H}$ NMR (CD $\left.{ }_{3} \mathrm{OD}, 500 \mathrm{MHz}\right) \delta 5.24$ (m, $\left.1 \mathrm{H}, \mathrm{H}-8\right)$, 4.36 (dd, H1, $\left.J_{5,4}=4.4 \mathrm{~Hz}, J_{5,6}=2.1 \mathrm{~Hz}, \mathrm{H}-5\right), 4.30\left(\mathrm{dd}, 1 \mathrm{H}, J_{7,6}=10.5, J_{7,8}=1.9 \mathrm{~Hz}, \mathrm{H}-7\right), 4.18(\mathrm{~m}, 1 \mathrm{H}, \mathrm{H}-4), 4.12\left(\mathrm{dd}, 1 \mathrm{H}, \mathrm{J}_{9,8}=9.0 \mathrm{~Hz}\right.$ $\mathrm{J}_{9,9^{\prime}}=11.5 \mathrm{~Hz}, \mathrm{H}-9$ ), 4.01 (dd, $\left.1 \mathrm{H}, J_{6,7}=10.5 \mathrm{~Hz}, \mathrm{H}-6\right), 3.84$ (dd, $1 \mathrm{H}, J_{9^{\prime}, 8}=2.5 \mathrm{~Hz}, J_{9^{\prime}, 9}=11.5 \mathrm{~Hz}, \mathrm{H}-9$ '), 3.83 (s, $3 \mathrm{H}, \mathrm{COOCH}$ ), 3.34 (s, 3H, $\left.\mathrm{OCH}_{3}\right), 2.06\left(\mathrm{~s}, 3 \mathrm{H}, \mathrm{OCOCH}_{3}\right), 2.02\left(\mathrm{dd}, 1 \mathrm{H}, J_{3 e q, 3 a x}=13.0 \mathrm{~Hz}, J_{3 e q, 4}=4.5 \mathrm{~Hz}, \mathrm{H}-3 \mathrm{eq}\right), 1.92,1.88(2 \times \mathrm{s}, 2$ x 3H, 2 x NHCOCH$), 1.75$ $\left(\mathrm{dd}, 1 \mathrm{H}, J_{3 a x, 3 e q}=13.0 \mathrm{~Hz}, J_{3 a x, 4}=11.5 \mathrm{~Hz}, \mathrm{H}-3 \mathrm{ax}\right), 0.88,0.85\left(2 \times \mathrm{x}, 2 \times 9 \mathrm{H}, 2 \times \mathrm{C}\left(\mathrm{CH}_{3}\right)_{3}\right), 0.10-0.05\left(\mathrm{~m}, 4 \times 3 \mathrm{H}, 2 \times \mathrm{Si}(\mathrm{CH})_{2}\right) ;{ }^{13} \mathrm{C}$ NMR (CD $\left.{ }_{3} \mathrm{OD}, 125 \mathrm{MHz}\right) \delta(\mathrm{ppm}) 173.5\left(\mathrm{OCOCH}_{3}\right), 172.8,172.2$ (2 x NHCOCH 3$), 169.7\left(\mathrm{CO}_{2} \mathrm{CH}_{3}\right), 100.8(\mathrm{C}-2), 78.5(\mathrm{C}-8), 70.6(\mathrm{C}-6)$, 66.6 (C-4), 64.9 (C-9), $53.1\left(\mathrm{CO}_{2} \mathrm{CH}_{3}\right), 52.4\left(\mathrm{OCH}_{3}\right), 50.7$ (C-7), $49.7(\mathrm{C}-5), 37.2(\mathrm{C}-3), 26.3\left(\mathrm{C}\left(\mathrm{CH}_{3}\right)_{3}\right), 26.2\left(\mathrm{C}\left(\mathrm{CH}_{3}\right)_{3}\right), 22.8,22.6(2 \mathrm{x}$ $\left.\mathrm{NHCOCH}_{3}\right), 21.2\left(\mathrm{OCOCH}_{3}\right), 19.0,18.9\left(2 \times \mathrm{SiC}\left(\mathrm{CH}_{3}\right)_{3}\right),-4.7,-4.8,-5.2\left(2 \times \mathrm{Si}\left(\mathrm{CH}_{3}\right)_{2}\right) ; \mathrm{LRMS}(+\mathrm{ESI}) \mathrm{m} / \mathrm{z}=671.27$ [M+Na] $]^{+} \mathrm{HRMS}$ (+ESI) Calc. for $\mathrm{C}_{29} \mathrm{H}_{56} \mathrm{~N}_{2} \mathrm{O}_{10} \mathrm{Si}_{2}[\mathrm{M}+\mathrm{Na}]^{+}$: 671.3366, found 671.3365.

Methyl (methyl-5,7-bis-acetamido-3,5,7-trideoxy-L-glycero- $\alpha$-L-manno-2-nonulopyranosid)onate (13). To a stirred solution of 12 (423 mg, $0.64 \mathrm{mmol})$ in THF: $\mathrm{H}_{2} \mathrm{O}(4: 1 \mathrm{v} / \mathrm{v}, 7.5 \mathrm{~mL})$ cooled to $0{ }^{\circ} \mathrm{C}$ was added trifluoroacetic acid $(149 \mu \mathrm{L}, 1.94 \mathrm{mmol})$. The resulting reaction mixture was allowed to warm to room temperature over 30 minutes and stirred for a further $24 \mathrm{~h}$ at room temperature. The reaction mixture was cooled to $0{ }^{\circ} \mathrm{C}$ and concentrated ammonia solution was added dropwise to neutralize the reaction. Once neutralized, the reaction mixture was concentrated in vacuo. Purification by flash column chromatography (eluent EtOAc/MeOH 4:1 v/v) afforded a mixture of products with differing degrees of acetylation. The product mixture was then diluted in anhydrous methanol (7 mL) before the addition of $0.5 \mathrm{M} \mathrm{NaOMe}$ solution in $\mathrm{MeOH}(400 \mu \mathrm{L})$. The reaction was stirred at room temperature under argon for $2 \mathrm{~h}$ before neutralizing with Amberlite IR-120( $\left.\mathrm{H}^{+}\right)$resin, filtered and concentrated in vacuo. Purification by flash column chromatography (eluent EtOAc/MeOH 4:1 v/v) afforded the desired triol 13 (172 mg, 71\% over 2 steps). [ $\alpha]_{\mathbf{D}}-75.1$ (c 1.00, MeOH); IR: 3273, 3082, 2957, 1741, 1639, 1556, 1375, 1275, 1161, 1052, $614 \mathrm{~cm}^{-1} ;{ }^{1} \mathrm{H}$ NMR $\left(\mathrm{CD}_{3} \mathrm{OD}, 500 \mathrm{MHz}\right) \delta 4.35$ (m, 1H, H-5), 4.19 (dd, $1 \mathrm{H}, J_{7,6}=10.4 \mathrm{~Hz}, J_{7,8}=2.8 \mathrm{~Hz}, \mathrm{H}-7$ ), 
4.15 (dd, $\left.1 \mathrm{H}, J_{6,7}=10.4 \mathrm{~Hz}, J_{5,6}=1.8 \mathrm{~Hz}, \mathrm{H}-6\right), 4.10$ (m, 1H, H-4), 3.84 (m, 1H, H8), 3.82 (s, 3H, COOCH $), 3.74\left(\mathrm{dd}, 1 \mathrm{H}, J_{9,8}=7.4 \mathrm{~Hz}\right.$, $\left.J_{9,9^{\prime}}=11.6 \mathrm{~Hz}, \mathrm{H}-9\right), 3.69\left(\mathrm{dd}, 1 \mathrm{H}, J_{9^{\prime}, 8}=4.4 \mathrm{~Hz}, J_{9^{\prime}, 9}=11.6 \mathrm{~Hz}, \mathrm{H}-9\right.$ '), $3.29\left(\mathrm{~s}, 3 \mathrm{H}, \mathrm{OCH}_{3}\right), 2.09\left(\mathrm{dd}, 1 \mathrm{H}, J_{3 e q, 3 a x}=13.0 \mathrm{~Hz}, J_{3 e q, 4}=4.8\right.$ Hz, H-3eq), 1.97, 1.92 (2 x s, 2 x 3H, 2 x $\mathrm{NHCOCH}_{3}$ ), 1.69 (dd, $\left.1 \mathrm{H}, J_{3 a x, 3 e q}=13.0 \mathrm{~Hz}, J_{3 a x, 4}=12.4 \mathrm{~Hz}, \mathrm{H}-3 \mathrm{ax}\right) ;{ }^{13} \mathrm{C} \mathrm{NMR}\left(\mathrm{CD}_{3} \mathrm{OD}, 125\right.$

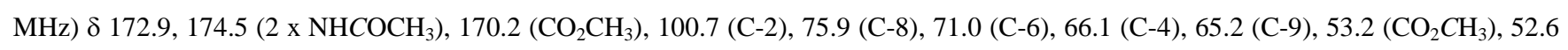
$\left(\mathrm{OCH}_{3}\right), 52.0$ (C-7), 49.9 (C-5), 36.2 (C-3), 22.9, 22.8 (2 x NHCOCH 3 ); LRMS (+ESI) m/z = 401.07 [M+Na] $]^{+}$HRMS (+ESI) Calc. for $\mathrm{C}_{15} \mathrm{H}_{26} \mathrm{~N}_{2} \mathrm{O}_{9}[\mathrm{M}+\mathrm{Na}]^{+}:$401.1531, found 401.1533.

Methyl (methyl-5,7-bis-acetamido-3,5,7,9-tetradeoxy-L-glycero- $\alpha$-L-manno-2-nonulopyranosid)onate (14). To a stirred solution of 13 (152 mg, $0.40 \mathrm{mmol})$ in anhydrous THF ( $5 \mathrm{~mL}$ ) was added triphenylphosphine (158 mg, $0.60 \mathrm{mmol})$, imidazole (55 mg, $0.80 \mathrm{mmol})$ and iodine (153 mg, $0.60 \mathrm{mmol})$. The resulting reaction mixture was heated at $60{ }^{\circ} \mathrm{C}$ for $2 \mathrm{~h}$ under argon. The reaction mixture was cooled to room temperature and $\mathrm{Na}_{2} \mathrm{~S}_{2} \mathrm{O}_{5}(114 \mathrm{mg}, 0.60 \mathrm{mmol})$ in $\mathrm{MeOH}(5 \mathrm{~mL})$ was added. The reaction mixture was adsorbed onto silica gel and concentrated to dryness. The residue was then purified by flash column chromatography (eluent EtOAc/MeOH 4:1 v/v) to afford the desired iodide. Due to inherent instability of the iodide, it was used immediately in the next transformation. The iodide was dissolved in anhydrous methanol $(2.5 \mathrm{~mL})$ before the addition of Hünig's base $(8.3 \mu \mathrm{L}, 0.05 \mathrm{mmol})$ and $\mathrm{Pd}(\mathrm{OH})_{2} / \mathrm{C}(20 \% \mathrm{wt})(27 \mathrm{mg})$. The reaction mixture was stirred at room temperature for $16 \mathrm{~h}$ under a hydrogen atmosphere. The reaction mixture was filtered to remove palladium, and the filtrate concentrated in vacuo. Purification by flash chromatography (eluent EtOAc/MeOH 4:1 v/v) afforded 14 (63 mg, $44 \%$ over 2 steps). $[\alpha]_{\mathbf{D}}-77.4$ (c 1.00, MeOH); IR: 3295 (br), 1745, 1702, 1655, 1554, 1438, 1371, 1273, 1222, 1202, 1164, 1134, 1111, 1093, 1053 cm ${ }^{-1} ;{ }^{1} \mathrm{H}$ NMR (D $\mathrm{O}, 500 \mathrm{MHz}): \delta 4.29$ (m, 1H, H-5) 4.24 (dd, $\left.1 \mathrm{H}, J_{6,7}=10.6 \mathrm{~Hz}, J_{7,8}=3.0 \mathrm{~Hz}, \mathrm{H}-7\right), 4.23-4.19$ (m, 2H, H-4/H-8), 3.93 (dd, $1 \mathrm{H}, J_{5,6}$ = $1.7 \mathrm{~Hz}, \mathrm{H}-6), 3.89$ (s, 3H, $\mathrm{CO}_{2} \mathrm{CH}_{3}$ ), $3.26\left(\mathrm{~s}, 3 \mathrm{H}, \mathrm{OCH}_{3}\right), 2.14$ (dd, 1H, J Jeq,3ax $\left.=13.6 \mathrm{~Hz}, J_{3 \mathrm{eq}, 4}=4.8 \mathrm{~Hz}, \mathrm{H}-3 \mathrm{eq}\right), 2.00,1.97$ (2 x s, 2 x 3H, 2 x NHAc), 1.73 (dd, 1H, $\left.J_{3 a x, 4}=12.2 \mathrm{~Hz}, \mathrm{H}-3 \mathrm{ax}\right), 1.18$ (d, 3H, $\left.J_{9,8}=6.05 \mathrm{~Hz}, \mathrm{H}-9\right) ;{ }^{13} \mathrm{C}$ NMR $\left(\mathrm{D}_{2} \mathrm{O}, 125 \mathrm{MHz}\right) \delta 174.9,173.9(2 \mathrm{x}$ NHCOCH 3$), 170.2\left(\mathrm{COCH}_{3}\right), 99.7$ (C-2), 70.7 (C-6), 67.0, 64.5 (C-4/C-8), $53.8\left(\mathrm{COCH}_{3}\right), 53.4$ (C-7), $51.7\left(\mathrm{OCH}_{3}\right), 48.5$ (C-5), $34.6(\mathrm{C}-3)$, 22.2, 22.1 (2 x $\mathrm{NHCOCH}_{3}$ ), 15.8 (C-9); LRMS (+ESI) $\mathrm{m} / \mathrm{z}=385.13$ [M+Na] $]^{+}$; HRMS (+ESI) Calc. for $\mathrm{C}_{15} \mathrm{H}_{26} \mathrm{~N}_{2} \mathrm{O}_{8}[\mathrm{M}+\mathrm{Na}]^{+}: 385.1581$, found 385.1584 . 
5,7-bis-Acetamido-3,5,7,9-tetradeoxy-L-glycero- $\boldsymbol{\alpha}$-L-manno-2-nonulosonic acid - Pse5Ac7Ac (1). To a solution of 14 (4.0 mg, 11 $\mu \mathrm{mol})$ in $\mathrm{H}_{2} \mathrm{O}(5 \mathrm{~mL})$ was added $1.0 \mathrm{M}$ aqueous $\mathrm{NaOH}$ solution $(0.3 \mathrm{~mL})$. The solution was heated at $40{ }^{\circ} \mathrm{C}$ for $1 \mathrm{~h}$ before adding freshly activated Dowex ${ }^{\circledR} 50 \mathrm{WX} 8\left(\mathrm{H}^{+}\right)\left(180 \mathrm{mg}\right.$, dry) which led to an acidic $\mathrm{pH}$. The solution was heated at $80^{\circ} \mathrm{C}$ for $36 \mathrm{~h}$ before cooling to rt and filtering off the resin. The filtrate was purified by RP HPLC (eluent: $0.1 \mathrm{vol} \%$ formic acid in $\mathrm{H}_{2} \mathrm{O}$, Waters Sunfire C18, $5 \mu \mathrm{m} 19 \mathrm{x} 150 \mathrm{~mm}$ with a flow rate of $7 \mathrm{~mL} / \mathrm{min}$, retention time $=5 \mathrm{~min}$ ). HPLC fractions containing 1 (detected by LC-MS, ESI+ mode) were lyophilised, affording 1 as a fluffy white solid (1.4 mg, 38\%). [ $\alpha]_{\mathrm{D}}-26.5$ (c 0.17, MeOH); IR: 3353 (br), 1735, 1702, 1625, 1560, 1467, 1421, 1369, 1293, 1231, 1094, 1040, 1010, 975, $942 \mathrm{~cm}^{-1} ;{ }^{1} \mathrm{H}-\mathrm{NMR}\left(\mathrm{D}_{2} \mathrm{O}, 500 \mathrm{MHz}\right): \delta 4.26$ (m, 1H, H-4), 4.21-4.10 (m, 3H, H-5/H-7/H-8), 4.05 (dd,

$\left.1 \mathrm{H}, J_{6,7}=10.4 \mathrm{~Hz}, J_{5,6}=1.7 \mathrm{~Hz}, \mathrm{H}-6\right), 2.02$ (s, 3H, NHAc), 1.97-1.95 (m, 4H, NHAc, H-3eq), 1.79 (t, $\left.1 \mathrm{H}, J_{3 \mathrm{ax}, 3 \mathrm{eq} / 4}=12.8 \mathrm{~Hz}, \mathrm{H}-3 \mathrm{ax}\right), 1.11$ $\left(\mathrm{d}, 1 \mathrm{H}, J_{8,9}=6.5 \mathrm{~Hz}, \mathrm{H}-9\right) ;{ }^{13} \mathrm{C}-\mathrm{NMR}\left(\mathrm{D}_{2} \mathrm{O}, 125 \mathrm{MHz}\right) \delta 176.6$ (C1), 175.6, 174.7 (2 x NHCOCH ), 97.6 (C-2), 70.9 (C-6), 67.7 (C-8),

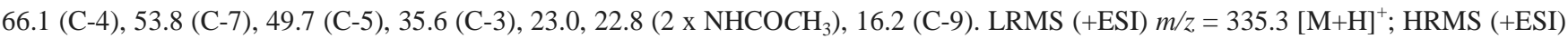
Calc. for $\mathrm{C}_{13} \mathrm{H}_{22} \mathrm{~N}_{2} \mathrm{O}_{8}[\mathrm{M}+\mathrm{Na}]^{+}$: 357.1268., found 357.1269. These data are fully consistent with those previously reported for the natural product. $^{27,29}$

\section{ASSOCIATED CONTENT}

\section{Supporting Information}

Materials and methods and ${ }^{1} \mathrm{H},{ }^{13} \mathrm{C}$ and $2 \mathrm{D}$ NMR spectra of novel compounds. This material is available free of charge via the Internet at http://pubs.acs.org.

\section{AUTHOR INFORMATION}

\section{Corresponding Author}

Email: richard.payne@sydney.edu.au, phone: +61 293515877

\section{Notes}

The authors declare no competing financial interests.

\section{ACKNOWLEDGMENT}

The authors wish to thank an Australian Research Council Future Fellowship (FT130100150) and the John Lamberton Research Scholarship and Australian Postgraduate Award schemes for PhD support.

\section{REFERENCES}

(1) Varki, A. Glycobiology 1992, 2, 25-40.

(2) Angata, T.; Varki, A. Chem. Rev. 2002, 102, 439-469.

(3) Chen, X.; Varki, A. ACS Chem. Biol. 2010, 5, 163-176.

(4) Kandiba, L.; Eichler, J. FEMS Microbiol. Lett. 2013, 345, 110-120. 
(5) Schauer, R. Curr. Opin. Struct. Biol. 2009, 19, 507-514.

(6) Wang, P.-H. J. Cancer Mol. 2005, 1, 73-81.

(7) Varki, A. Trends Mol. Med. 2008, 14, 351-360.

(8) Knirel, Y. A.; Shevelev, S. D.; Perepelov, A. V. Mendeleev Commun. 2011, 21, 173-182.

(9) Zunk, M.; Kiefel, M. J. RSC Adv. 2014, 4, 3413-3421.

(10) Matthies, S.; Stallforth, P.; Seeberger, P. H. J. Am. Chem. Soc. 2015, 137, 2848-2851.

(11) Thibault, P.; Logan, S. M.; Kelly, J. F.; Brisson, J. R.; Ewing, C. P.; Trust, T. J.; Guerry, P. J. Biol. Chem. 2001, 276, 34862-34870.

(12) Logan, S. M.; Kelly, J. F.; Thibault, P.; Ewing, C. P.; Guerry, P. Mol. Microbiol. 2002, 46, 587-597.

(13) McNally, D. J.; Hui, J. P. M.; Aubry, A. J.; Mui, K. K. K.; Guerry, P.; Brisson, J-R.; Logan, S. M.; Soo, E. C. J. Biol. Chem. 2006, 281, 18489-18498.

(14) Zampronio, C. G.; Blackwell, G.; Penn, C. W.; Cooper, H. J. J. Proteome Res. 2011, 10, 1238-1245.

(15) Ewing, C. P.; Andreishcheva, E.; Guerry, P. J. Bacteriol. 2009, 191, 7086-7093.

(16) Schirm, M.; Soo, E. C.; Aubry, A. J.; Austin, J.; Thibault, P.; Logan, S. M. Mol. Microbiol. 2003, 48, 1579-1592.

(17) Hopf, P. S.; Ford, R. S.; Zebian, N.; Merkx-Jacques, A.; Vijayakumar, S.; Ratnayake, D.; Hayworth, J.; Creuzenet, C. PLoS One 2011, 6. e25722.

(18) Knirel, Y. A.; Vinogradov, E. V.; Lvov, V. L.; Kocharova, N. A.; Shashkov, A. S.; Dmitriev, B. A.; Kochetkov, N. K. Carbohydr. Res. 1984, 133, C5.

(19) Knirel, Y. A.; Shashkov, A. S.; Tsvetkov, Y. E.; Jansson, P. E.; Zähringer, U. Adv. Carbohydr. Chem. Biochem. 2003, 58 , 371-417.

(20) Kenyon, J. J.; Marzaioli, A. M.; Hall, R. M.; De Castro, C. Glycobiology 2014, 24, 554-563.

(21) Parker, J. L.; Day-Williams, M. J.; Tomas, J. M.; Stafford, G. P.; Shaw, J. G. MicrobiologyOpen 2012, 1, 149-160.

(22) Wilhelms, M.; Fulton, K. M.; Twine, S. M.; Tomas, J. M.; Merino, S. J. Biol. Chem. 2012, 287, 27851-27862.

(23) Logan, S. M. Microbiology 2006, 152, 1249-1262.

(24) Guerry, P.; Ewing, C. P.; Schirm, M.; Lorenzo, M.; Kelly, J.; Pattarini, D.; Majam, G.; Thibault, P.; Logan, S. Mol. Microbiol. 2006, 60, $299-311$.

(25) Stephenson, H. N.; Mills, D. C.; Jones, H.; Milioris, E.; Copland, A.; Dorrell, N.; Wren, B. W.; Crocker, P. R.; Escors, D.; Bajaj-Elliott1, M. J. Infect. Dis. 2014, 210, 1487-1498.

(26) Menard, R.; Schoenhofen, I. C.; Tao, L. M.; Aubry, A.; Bouchard, P.; Reid, C. W.; Lachance, P.; Twine, S. M.; Fulton, K. M.; Cui, Q. Z.; Hogues, H.; Purisima, E. O.; Sulea, T.; Logan, S. M. Antimicrob. Agents Chemother. 2014, 58, 7430-7440.

(27) Schoenhofen, I. C.; McNally, D. J.; Brisson, J. R.; Logan, S. M. Glycobiology 2006, 16, 8C-14C.

(28) Chou, W. K.; Dick, S.; Wakarchuk, W. W.; Tanner, M. E. J. Biol. Chem. 2005, 280, 35922-35928.

(29) Tsvetkov, Y. E.; Shashkov, A. S.; Knirel, Y. A.; Zähringer, U. Carbohydr. Res. 2001, 335, 221-243.

(30) Lee, Y. J.; Kubota, A.; Ishiwata, A.; Ito, Y. Tetrahedron Lett. 2011, 52, 418-421.

(31) Zunk, M.; Williams, J.; Carter, J.; Kiefel, M. J. Org. Biomol. Chem. 2014, 12, 2918-2925.

(32) Albler, C.; Hollaus, R.; Kählig, H.; Schmid, W. Beilstein J. Org. Chem. 2014, 10, 2230-2234.

(33) Kiefel, M. J.; Wilson, J. C.; Bennett, S.; Gredley, M.; von Itzstein, M. Bioorg. Med. Chem. 2000, 8, 657-664. 